\title{
Gender bias in media representation of political actors: Examples from Nigeria's 2015 presidential election
}

\author{
Babatunde Raphael Ojebuyi \\ Lecturer \\ Department of Communication and Language Arts, Faculty of Arts \\ University of Ibadan, Nigeria \\ E-mail: br.ojebuyi@mail1.ui.edu.ng; ojebabson@gmail.com

\section{Anne Chiamaka Chukwunwike} \\ Student Researcher \\ Department of Communication and Language Arts, Faculty of Arts \\ University of Ibadan, Nigeria \\ E-mail: winke.anne@gmail.com
}

Submitted: August 4, 2017 / Accepted: March 27, 2018 / Published: June 8, 2018

\begin{abstract}
As in other parts of the world, the Nigerian news media, in its coverage of electioneering, has been accused of marginalizing female politicians. To establish the veracity of this claim, we examined how Nigerian newspapers reported campaign activities of the major presidential candidates during Nigeria's 2015 presidential election. Using the theories of media framing and market-oriented journalism, we undertook content analysis of 194 editions of three randomly selected newspapers - The Punch, The Guardian and the Daily Sun. The findings confirmed a media framing that marginalized female politicians as Nigerian newspapers gave prominence and intense coverage to male presidential aspirants as opposed to their female counterparts.
\end{abstract}

Keywords: Nigeria's 2015 presidential election, gender and politics, media coverage electioneering, media framing.

\section{Introduction}

In every democratic society, the media is considered significant because of its roles in informing, sensitizing, and mobilizing the populace. Given the popularity and acceptance of democracy as the modern form of governance in most countries of the world, political activities often and naturally enjoy media preference in terms of reportage (Graber, 1996). The significance of the media is particularly eminent during elections wherein 
the need for information to empower the citizens to participate in politics becomes critical. The objective reporting of political matters by the media further enables the electorate to be familiar with the issues and information germane to governance, those who control the affairs of the state, or those who are aspiring to rule (Dimitrova, Sheheta, Stromback \& Nord, 2014). The media drives electioneering processes and enables the masses to make informed political decisions and take judicious action in terms of electing leaders.

During the election time, citizens are likely to rely heavily on the media to get information about aspiring political leaders and party candidates. The information around manifestoes and the ideological stance of each aspirant would arm the electorate to take the right decisions at polls. However, the objectivity of journalists in reporting socio-political issues often determine the level of trust the citizens have in the media to serve the political system (Oso, 2012; Bucy, D’Angelo \& Bauer, 2014; Carkoglu, Baruh \& Yildirim, 2014). Lack of objectivity is an ethical problem. Journalists are expected to detach themselves from authorial influence, political ideology, personal opinion, or partisan stance (Nassanga, 2008; Oso, 2012; Adaja, 2013). In a situation where the journalist is driven by these negative values, the citizenry become the prime victims as they may be fed with skewed information capable of influencing them to give the news story wrong interpretations and take wrong decisions that may have grave consequences for the political system. One of the ways in which journalists could violate the moral principle of fairness (Ayodele, 1988; Nassanga, 2008; Tucher, 2009) during elections is the manner in which they represent the political candidates. Factors such as ownership, ethnicity, religion, political affiliation, commercial proposition Agbalajobi (2010) and gender chauvinism could drive journalists to sacrifice fairness during the coverage of elections. For instance, it has been argued that female presidential candidates are silent in electoral races and the media are blamed for this absence (Thorsten, 2005; Ette, 2017). This phenomenon implies that females do not enjoy the privilege of being well represented in the presidential 
Ojebuyi, B. R. \& Chukwunwike, A. C./ Legon Journal of the Humanities 29.1 (2018)

race (Ette, 2017) and are, therefore, deprived from enjoying the freedom of free expression and inclusion that underscore the values of a true democracy.

\section{The problem}

The phenomenon of unequal gender representation in Nigeria's political framework is not debatable. Most of the highprofile political seats such as the National Assembly leadership, the position of the Vice-President and the exalted office of the President are, seemingly as a default, occupied by males (Inter-Parliamentary Report, 2007; Sankore, 2017). It has been observed that gender inequality in Nigerian politics seems to have been institutionalized as only $5.6 \%$ of members of the 8 th National Assembly inaugurated on June 9, 2015 are women. This figure indicates that "Nigeria has the lowest representation of female parliamentarians in Africa and the tenth lowest out of 190 parliaments globally" (Sankore, 2017, p. 56). Although there was a time when Nigeria produced the first female speaker (Patricia Etteh) for the House of Representatives, her tenure was short-lived as a result of intense political intrigues. To buttress this lack of equity in the gender representation in Nigerian politics, Ajayi (2007) and the Inter-Parliamentary Report (2007) have also observed and documented the lack of intense competition between the male and the female political candidates vying for the same political seat. In his argument regarding unequal gender representation, Ryan (2013) has blamed this situation of skewed male-female representation and eventual emergence and re-emergence of male dominance in the Nigerian political terrain on the lack of balanced and intense media coverage of female candidates in electoral contests.

Gender imbalance in Nigeria is not limited to political representation; it is a phenomenon that affects all societal spheres in the country. Scholars (e.g. Salawu, 2006; Mudhai, Wright \& Musa, 2016) have argued that, unlike the case in Kenya and South Africa with improved gender representation, the Nigerian media environment, especially with regard to training and practice, is plagued with social and cultural practices that discriminate 
against women; and is skewed with respect to media ownership, practice, access and use, especially as the overall media terrain is dominated by men (Ngwu, 2015). Also, while executing the Amnesty Programme in the Niger Delta of Nigeria, the political actors and concerned government agencies grossly marginalized women: Palliative measures to the militancy crisis in the Niger Delta were applied without addressing the issue of gender in the conceptualization of strategic political and economic stability in the region as government employed a purely masculine approach to the problems (Amusan, 2014). Despite the gender-dominated political terrain, in 2015, Nigeria's political history recorded a landmark as the first female presidential candidate, Professor (Mrs.) Comfort Oluremi Sonaiya, took part in the electoral contest under the banner of the KOWA Party (the Vanguard [Nigeria], 18 March 2015). But how the media represented Mrs. Remi Sonaiya as a female presidential candidate is still a subject of debate.

To investigate the foregoing argument that women have not been fairly represented by Nigerian media, scholars such as Oyesomi and Oyero (2012) conducted a newspaper coverage of female politicians but limited the investigation and analysis to the 2011 gubernatorial elections just to find out the visibility of female politician-candidates in Nigerian politics. The study reported low media coverage of female participation in politics. Also, Ette (2017, p. 1480) examines the spatial representation of Nigerian women politicians in the news media of Nigeria during the 2015 general elections. The findings of the study show that "women do not only occupy limited space in the news media but are also marginalized in political news despite decades of advocacy for gender equality". Ette, therefore, argues that the limited visibility of women in political news encourages marginalization and "reinforces assumptions that "only men do politics". The author also inferred that Nigerian news media, with its scant attention given to women in politics, "reinforces patriarchal understanding of politics and consequently highlights the manifest and latent obstacles that women encounter in the political arena" (p. 1480). Other scholars (e.g. Fatile, Olufemi, Ighodalo, Igbokwe, Chiyeaka, Oteh \& Chukwuemeka, 2012; 
Ojebuyi, B. R. \& Chukwunwike, A. C./ Legon Journal of the Humanities 29.1 (2018) Ugwuede, 2014) in similar studies also captured the challenges of female politicians' participation which have resulted in the low visibility of female politician-candidates at elections. The common trend established by the studies was that as a result of the lack of financial capacity and socio-cultural beliefs, female political candidates themselves believe that there are no opportunities for them to hold influential political positions. This phenomenon could also contribute to the low media attention female politiciancandidates receive at election times.

Despite various studies on participation of women politicians and media attention they receive (e.g. Quadri, 2015; Isika, 2016; Ette, 2017), how Nigerian newspapers represented the only female presidential candidate during the 2015 presidential elections in Nigeria in terms of the degree and nature of media attention the female politician got compared to her male counterparts has not received ample scholarly attention. This study, therefore, carried out a gender-based comparative analysis of media coverage of the presidential candidates during Nigeria's 2015 presidential election with a view to establishing the difference, if any, in how Nigerian newspapers reported electioneering activities of the only female presidential candidate and those of her male counterparts. The selected presidential candidates are Comfort Oluremi Sonaiya of the KOWA Party, Goodluck Ebele Jonathan of the People's Democratic Party (PDP), and Muhammadu Buhari of the All Progressives Congress (APC). Muhammadu Buhari is a former military Head of State from 31 December 1983 to 27 August 1985; Goodluck Jonathan served as Governor of Bayelsa State from 2005 to 2007 and Nigerian Vice-President from 2007 to 2010, while Mrs. Oluremi Sonaiya, a retired Professor of French Language and Applied Linguistics, never occupied any exalted political office. The presidential candidates were selected for two reasons: One, Mrs. Sonaiya was the only female candidate in the election and first in Nigeria's political history; two, while Goodluck Jonathan was the flag bearer of the ruling party (PDP), Muhammadu Buhari was the presidential candidate of the mega-opposition party (APC). 
It was believed that the three candidates, given their political peculiarities, would attract more media attention and could reflect patterns of media coverage of political actors of the presidential election. To achieve the study objectives, we answered this core research question: What is the degree of prominence, especially in terms of gender-based difference in coverage, given to the presidential candidates by the selected newspapers? To answer this question, we also tested the Null Hypothesis (HO): There will be no statistically significant difference in the scores for the male aspirants and the female aspirant in terms of media coverage they received during Nigeria's 2015 presidential election. Findings of this study did not just reveal the nature and degree of coverage given to the political candidates but also established the level of balance and fairness exercised by the Nigerian newspapers in their representation of the sole female presidential aspirant compared with her male counterparts. The study provided further basis for understanding whether or not Nigerian news media ensures gender parity in serving the nation's democracy, particularly in how they report political matters.

\section{Literature review}

\section{Media and coverage of electoral contests}

While an election is one of the fundamental components of democracy because of the ballots through which citizens choose their government representatives, the media provides the platform for public debates and exchange of political ideals and ideologies. Of course, the media cannot be left out of electioneering and general electoral activities. It plays a critical role in the political system by providing a link between politicians and the citizens (Atkinson \& Krebs, 2008). In supporting this assertion, Ace Project (2012) submits that modern-day elections are impossible without the media. Right from the era of colonialism to the current democratic dispensation, the media has consistently served as an important avenue for political education and information dissemination. The media as an institution serves as the channel of communication and information for the electorate. In espousing this critical position of 
the media in the electoral process, Ibraheem, Ogwezzy-Ndesikka and Tejumaiye (2015) contend that the media has the power to control and condition the thinking of the electorate, especially during an election year when they have to make choices among different political candidates seeking public offices. This implies that the media serves as agent of power and political control and can influence the perceptions of the electorate about the political system and their government representatives.

While reporting electioneering activities, journalists serve as gatekeepers (Shoemaker, Eichholz, Kim \& Wrigley, 2001; McKain, 2005; McQuail, 2007; Barzinlai-Nahon, 2008) who decide which information, ideologies, or political aspirants receive prominence and are reported in positive tones. The extent to which journalists adhere to the principles of fairness, balance, and objectivity in applying the news selection criteria (Shepard, 1999; McGregor, 2010) defines the quality of information the electorate get during elections. As much as balanced and fair representations of all political aspirants and their manifestoes would arm the electorate to take guided decisions and choose the right leaders, skewed and biased representations of political aspirants could have grave consequences for the democratic project as citizens are likely to make wrong decisions that could spell doom for the political system.

\section{Review of some empirical studies on media and coverage of gender during electoral contests}

It is considered particularly important to explore the myriad of arguments and some existing studies on the issue of gender in media coverage during electoral contests. According to Thorsten (2005) the media employs a gender filter in the coverage of election and the reporting of political candidates. This gender filter is an instrument of exclusion or integration that the media employs in representing both genders vying for the same electoral seat. As reported by Anorue, Obayi and Onyebuchi (2012) and Oyesomi and Oyero (2012), although the media coverage given to female political candidates is usually low, the tone used by media to report 
the female candidates are somewhat favorable. The implication is that even though the female politicians are likely to be reported in a more favorable tone compared to how men are reported, womenpoliticians may not enjoy the same level of prominence their men counterparts enjoy. A study in Kenyan by African Women and Child Future Service (2013) is similar to the Nigerian case. The authors find that $1 \%$ of what is seen or read in the print and broadcast media was about female politicians in contrast to reports on the male politicians which were aggregated at $74 \%$.

In studies in the Western context, however, male and female candidates received almost equal attention from newspapers (Hayes, Lawless \& Baitinger, 2014; Hayes \& Lawless, 2015). The authors, however, fail to clarify if there are gender-biased tones in media coverage of the candidates. A study by Aalberg and Jenssen (2007) in Norway investigated the media coverage of male and female political candidates during electoral contests. It was recorded that the media gave $42.2 \%$ coverage to women contesting in an election, a finding that seems to confirm Hernes' (1987) assertion that Norway is not a male-chauvinist state. However, the study also established that, influenced by how the media represents the male political candidates, the electorate see male politicians as being more knowledgeable, convincing and trustworthy than the female aspirants. This could provide a scenario that is contrary to what obtains in Nigeria where women have remained under-reported and perpetual victims of cultural discrimination and failing statehood (Ette, 2017; Onyenwere, 2017).

It could be inferred from the foregoing empirical evidence that, overall, female political actors do not receive the same level of treatment by the mass media. However, scholars have argued that the media could not be totally blamed for this seeming bias, as other factors could be responsible. For instance, Aluaigba (2015) posits that the funding of candidates in an electoral contest is a necessity for media coverage of political candidates. This implies that he who pays the piper calls the tune; without sufficient funds, there will be inadequate media coverage of electoral activities. Using empirical evidence to explain the gender disparities in the media coverage of 
politics, Agbalajobi (2010) conducted a study and found a twist, shifting the blame away from the media. The study linked unequal media coverage of gender in political race to lack of financial backing, political violence, lack of self-confidence, and illiteracy. The research finding could imply that to be politically strong in the media coverage of electoral contests, political candidates, regardless of their gender, should have strong financial backing, technical capability to handle the violent dramas that might come up, and have good educational qualifications.

As reported by the Vanguard newspaper [Nigeria] (23 March, 2015), with only five days to 28 March 2015 elections, major political parties, friends and well-wishers of those contesting for elective offices spent N4.9 billion (about 24.6 million USD then $)^{1}$ on advertisement alone. The details provided by the report show that only the ruling party (PDP) and the main opposition party (APC) had stronger financial capacity than other parties. Based on this evidence that huge amount of money was invested in advertisement by most of the political parties to participate in electoral contests, it can be inferred that the media cannot be totally blamed for projecting certain presidential candidates more than the others. The literature has shown that across the world, there are always instances of gender disparity in how the media projects political actors, especially during elections, but this phenomenon could vary from one country to another or from one period of time to another. Therefore, there is still the need to investigate how the media represented the political aspirants in Nigeria's presidential election of 2015, which marked the first time in Nigeria's political history when a political party (i.e. The KOWA ${ }^{2}$ Party) would field a woman as its presidential flag bearer in the person of Professor (Mrs.) Comfort Oluremi Sonaiya (Isika, 2016). Compared to

1 The exchange rate during the period leading to the 2015 elections was N199.257 to 1USD. Therefore, N4.9 billion times $\$ 199.257$ would give 24.6 million USD.

2 KOWA is not an acronym, but is written in capital letters. It is a word that has different meanings in different Nigerian languages. For example, in Igbo, KOWA means "explain". The word could also mean "openness" and "transparency". In Hausa, KOWA means "everybody". This suggests "all of us are members", "our own party". In Yoruba, KOWA means "let it come". This could suggest "let the good life come". It could also suggest "positive change", the party's main campaign mantra during the 2015 general elections. 
Ojebuyi, B. R. \& Chukwunwike, A. C./ Gender bais in media representation of political actors previous studies on Nigeria's 2015 general elections, our current study is unique in terms of its emphasis. For instance, while Ette's (2017) study focused on news media representation of Nigerian women candidates during the 2015 general elections, our study is more specific as it focuses on how the Nigerian newspapers reported Mrs. Sonaiya, the only female presidential candidate, compared to how the media reported the flag bearers of the ruling party (Goodluck Jonathan of PDP) and the mega-opposition party (Muhammadu Buhari of APC).

\section{Theoretical framework}

Two theories are adopted for this study - the Media Framing and the Market-Oriented Journalism theories. Framing, as related to the mass media, is defined by McCombs $(2004$, p. 87) as the selection of, and placing emphasis on, particular attributes for the news media agenda when talking about an object, an issue, or a person (i.e. the fact of cutting and trimming a news story in order to filter it and shape it as the sender wishes). Entman (2007) explains that to frame is to select some fragments of social issues and make them more significant and salient than others in a communicating context. The primary aim of framing is to promote or suggest causal interpretation, definition, moral evaluation, or treatment of a perceived reality. The nature of these framing elements would always influence the interpretation that the audience would give to the communicated message. Another definition is provided by Severin and Tankard (2001), who define framing in news media as the process of structuring news content through selection, emphasis, inclusion, exclusion, and elaboration. The media actors decide what to emphasize, what to suppress or what to exclude from the media content (Druckman, 2001; Scheufele \& Tewksbury, 2007).

The underlying tenet of the media framing theory is that the mass media uses frames to structure and draw attention of the mass audience to certain public issues in such a manner that does not only communicate the salient issues of the day but also dictates the media's preferred slants that may influence how the audience perceive the issues. The theory operates on the notion that 
journalists' influence on selection and salience (i.e. how an issue or person is characterized in a news report) in terms of variables such as placement and space, can have an impact on how the mass audience interpret the story (Entman, 1993; Scheufele \& Tewksbury, 2007). In other words, the journalists, acting as gatekeepers, select certain frames of public issues which could influence how the audience think about or react to such issues in the context supplied by the media. Since the assumption in our current study is that Nigerian newspapers would exhibit unequal gender representation in their framing of political aspirants during the 2015 general elections in Nigeria, the Media Framing Theory is, considered appropriate for the study. The theory guided our selection of units of analysis and construction of the content analytical categories.

The second theory we selected for this study is the MarketOriented Journalism Theory of news production. The theory, as noted by McManus (2005), is premised on the notion that media outfits are business-oriented and profit-driven. In other words, for the media to survive, they seek revenue to publish news. The interest and the cost of uncovering and reporting an event constitute the core tenets of the market-oriented journalism theory. McManus (2005) anchors the principle of the market-oriented journalism theory on the proposition, among others, that the probability of an event becoming what the media selects as news is directly proportional to the expected breadth of appeal of the story to the larger audiences and what advertisers will pay to reach the audience. Based on the tenets of this theory, it becomes clear that it is not just about reporting news but also about reporting news and events that will bring economic benefit to the news agency. This, in the context of this study, suggests that for the electoral activities of candidates to be reported or publicized, political candidates are supposed to run campaigns, hold political rallies, establish projects and pay the media to report such events. In other words, to receive the media attention and consequently become popular among the electorate, an aspiring politician will have to pay the media.

The relevance of the market-oriented theory to this study 
Ojebuyi, B. R. \& Chukwunwike, A. C./ Gender bais in media representation of political actors

is based on the fact that there is a connection between the framing theory and the market-oriented journalism theory especially in the gatekeeping process (Shoemaker, Eichholz, Kim \& Wrigley, 2001; Shoemaker, 2006). While making editorial decisions, there are some external variables that affect what journalists select as news and how such items selected are framed. These variables include market forces, political alliances, and influence of competitors, (McManus, 2005; Shoemaker \& Vos 2009; Reese \& Ballinger, 2001; Ojebuyi, 2012). This connection provides the basis for understanding how variables such as market orientation affect the final product that the news media gives to the audience (Ferrucci, 2015). As a matter of fact, all media organizations are, to a certain extent, marketoriented (Beam, 1998; Beam, 2001). The media outfits in Nigeria are profit-oriented given the fact that the media industry in the country operates in a neo-liberal context that encourages profitdriven enterprises (Akinfeleye, 2008; Ojebode, 2009; Olorunnisola, 2009). This suggests that the amount of prominence or coverage the media selected for this study gave to the political candidates might, to a degree, be determined by the financial capability of such candidates or their parties.

\section{Method and materials}

\section{Methodology}

The primary aim of this research was to establish the extent of gender disparities in the media coverage given to Oluremi Sonaiya, the presidential candidate of the KOWA Party as opposed to the coverage given to Goodluck Jonathan of the People's Democratic Party and Muhammadu Buhari of the All Progressives Congress party. We employed content analysis as the research method focusing on the print media. Initially, six newspapers were purposively selected based on the criteria of geographical appeal, wide readership base, and national coverage. The selected newspapers are The Nation, the Vanguard, The Guardian, The Nigerian Tribune, The Daily Trust, and The Daily Sun. Out of these six, three newspapers (i.e. The Punch, The Guardian, and the 
Daily Sun) were randomly selected for final analysis. A total of 375 editions were purposively selected from 15 November 2014 to 20 March 2015 because the period marked the peak of electoral activities in Nigeria (BBC News, 2015). Only editions that reported political stories, articles or pictures of the presidential candidates were first considered. Through a systematic random sampling, 194 editions were finally selected from the purposively selected 375 editions, with a sample size of 194 stories calculated based on the simple model as shown below:

$$
\mathrm{n}=\frac{\mathrm{N}}{1+\mathrm{N}(\mathrm{e})^{2}}
$$

Where, $\mathrm{n}=$ the required sample size.

$\mathrm{N}=$ Total population of the study

$\mathrm{e}=$ the expected error $(0.05)$

$1=$ Constant

$$
\mathrm{n}=\frac{375}{1+375(0.05) 2}
$$

$$
\mathrm{n}=\frac{375}{1+375(0.0025)}
$$

$$
\mathrm{n}=\frac{375}{1+0.9375}
$$

$\mathbf{n}=194$

From the total sample of 194 editions of the selected newspapers, we looked for pure editorial contents on political stories (i.e. hard news, features, and editorials). To complement the editorial contents, we also considered the extra-editorial components (e.g. paid adverts, personality profiles, and profile pictures) that 
Ojebuyi, B. R. \& Chukwunwike, A. C./ Gender bais in media representation of political actors

related to Muhammadu Buhari (APC), Comfort Olueremi Sonaiya (The KOWA Party), and Goodluck Jonathan (PDP). We got a total of 565 content matters that we finally analysed.

\section{Unit of analysis and content categories}

Our choice of the unit of analysis and content categories for coding and analysis was guided by the tenet of the Media Framing Theory, which explains that selection and salience (i.e. how an issue or a person is characterized in a news report) in terms of variables such as placement and space, can have an impact on how the mass audience interpret the story (Entman, 1993; Scheufele \& Tewksbury, 2007).

Each news story, article, or picture on the presidential candidates of the three political parties (KOWA, PDP, and APC) was the unit of analysis that we analysed. In order to establish the extent of coverage and prominence given to the candidates, we used story placement, formats, and amount of space given to an individual story. These three variables are components of the macroconstruct of framing journalists often use to construct news stories in a way that "resonates with existing underlying schemas among their audience" (Scheufele \& Tewksbury, 2007, p. 12). Further, we disaggregated the story formats into editorial contents (i.e. hard news, features/soft news, and editorials) and extra-editorial contents (i.e. advertisements, profile pictures, and personality profiles). What informed this disaggregation was our belief that the selection of the extra-editorial content would be influenced more by profit-driven preference as espoused in the tenets of MarketOriented Journalism Theory. The content categories are explained as follows:

Placement of the reports: This was the positioning of the news items on the pages of the newspapers whether on the front, inside, or back of the newspapers:

a. Front page: any of the story formats about the candidates found on the first page. 
Ojebuyi, B. R. \& Chukwunwike, A. C./ Legon Journal of the Humanities 29.1 (2018)

b. Back page: any of the story formats about the candidates found on the last page.

c. Inside page: any of the story formats about the candidates found on the inside pages of the newspapers.

Format: This refers to the type of news or stories that were used to report the presidential candidates. Here, we have two formats: editorial contents (hard news, features/soft news, and editorials) and extra-editorial contents (advertisements, profile pictures, and personality profiles).

a. Hard news: These are current news stories reporting the political activities of the presidential candidates. They are straight-forward news typically believed to be factual and unbiased, and not to have been sponsored by news actors.

b. Editorials: These refer to the newspaper judgement or opinions on the presidential candidates.

c. Features: They are extended stories in the column sections that directly or indirectly refer to the presidential candidates.

d. Personality Profiles: These are interviews and autobiographies of the candidates done to promote the political credentials of the candidates.

e. Advertisements: These are sponsored messages which were meant to promote political interest of the affected presidential candidates.

f. Profile Pictures: These are pictorial representations of the presidential candidates; they were used solely to project the image of the aspirants.

Space: This refers to the size or length of the story formats on the pages of the newspaper. Space could be captured in the following ways: 
Ojebuyi, B. R. \& Chukwunwike, A. C./ Gender bais in media representation of political actors

a. Short length: These are stories with the size below midpoint of the newspaper.

b. Medium length: These are stories that do not extend beyond the mid-point of the page of the newspaper.

c. Long length: These are stories with the size above the midpoint of the page of the newspaper.

\section{Validity and reliability of the instrument}

In order to gather appropriate and relevant data for this study, the instrument to be used for the research was tested for validity and reliability. Thus, an inter-coder reliability test was conducted among two coders. As Wimmer and Dominick (2011) explain, the inter-coder test helps the researcher to achieve an objective and reliable result. We used Holsti's (1969) formula for the inter-coder reliability test as presented by Wimmer and Dominick (2011):

$$
\text { Reliability }=\frac{\mathbf{2 N}}{\mathbf{N}_{\mathbf{1}}+\mathbf{N}_{\mathbf{2}}}
$$

$\mathbf{N}$ represents the number of coding decisions with which the two coders agree where $\mathbf{N} 1$ and $\mathbf{N} 2$ are the total number of the coding decisions by the first coder and the second coder respectively. The inter-coder reliability test was carried out on $10 \%$ of the selected stories. As decided by two independent coders, the test showed $\mathbf{0 . 8 1}$ reliability index. This means that the coding sheet was reliable and capable of producing valid results as the two coders agreed on almost all the content categories applied to the sample selected.

\section{Results}

We presented the results according to the categories of placement, space, and format. These are the components of macroconstruct of framing (Scheufele \& Tewksbury, 2007) that guided our analyses. We also accounted for extra-editorial contents (i.e. advertisements, profile pictures, and personality profiles) that could be functions of the financial strength of the candidates or 
Ojebuyi, B. R. \& Chukwunwike, A. C./ Legon Journal of the Humanities 29.1 (2018) their political parties rather than being subjected to pure editorial manipulation by journalists. Overall, a total of 565 content matters on the three presidential candidates were analyzed. From the gender perspective, our findings show an imbalanced structure in the pattern of media attention the three candidates received during the 2015 electioneering.

Placement As presented in Table 1 below, Muhammadu Buhari got $37.9 \%$ and $45.7 \%$ of front-page and back-page reports respectively; Goodluck Jonathan got $62.1 \%$ of front-page reports and $54.3 \%$ of back-page reports. As expected, given the trend already established in the literature, Sonaiya did not receive any coverage on the front and back pages of the selected newspapers. The scanty eight reports on her constituting only $1.4 \%$ of the total items analysed were found on the inside pages of the newspapers.

Table 1: Placement of coverage given to the presidential

\begin{tabular}{|l|l|l|l|l|}
\hline \multirow{2}{*}{ CANDIDATES } & \multicolumn{4}{|c|}{ PAGES } \\
\cline { 2 - 5 } & Front & Inside & Back & Total \\
\hline & F (\%) & F (\%) & F (\%) & F (\%) \\
\hline Buhari & 24 & 218 & 16 & 258 \\
& $(37.9)$ & $(46.8)$ & $(45.7)$ & $(45.7)$ \\
\hline Jonathan & 41 & 239 & 19 & 299 \\
& $(62.1)$ & $(51.1)$ & $(54.3)$ & $(52.9)$ \\
\hline Sonaiya & 0 & $8(1.7)$ & 0 & 8 \\
& $(0.00)$ & & $(0.00)$ & $(1.4)$ \\
\hline Total & 66 & 464 & 35 & 565 \\
& $(100)$ & $(100)$ & $(100)$ & $(100)$ \\
\hline
\end{tabular}

\section{Space}

The extent of media coverage given to the three candidates based on space allocated as presented on Table 2 indicates that, 
Ojebuyi, B. R. \& Chukwunwike, A. C./ Gender bais in media representation of political actors

overall, Jonathan got the most media space $(n=299 ; 52.9 \%)$ among the three candidates. From the gender angle, however, the two male candidates got more media space than did the female candidate. Jonathan was given more space with $54.5 \%$ of long-length reports and $54.1 \%$ of short-length news stories while Buhari was given $44.1 \%$ of long-length stories and $44.0 \%$ of short-length stories respectively. Conversely, Sonaiya recorded only $1.4 \%$ of longlength stories and $1.8 \%$ of short-length stories.

Table 2: Percentage coverage given to the presidential candidates based on space

\begin{tabular}{|l|c|c|c|c|}
\hline \multirow{2}{*}{ CANDIDATES } & \multicolumn{4}{|c|}{ SPACE } \\
\cline { 2 - 5 } & Long & Medium & Short & Total \\
\hline \multirow{2}{*}{ Buhari } & F (\%) & F (\%) & F (\%) & F (\%) \\
& 126 & 84 & 48 & 258 \\
& $(44.1)$ & $(49.4)$ & $(44.0)$ & $(45.7)$ \\
\hline Jonathan & 156 & 84 & 59 & 299 \\
& $(54.5)$ & $(49.4)$ & $(54.1)$ & $(52.9)$ \\
\hline Sonaiya & 4 & 2 & 2 & 8 \\
& $(1.4)$ & $(1.2)$ & $(1.8)$ & $(1.4)$ \\
\hline Total & 286 & 170 & 109 & 565 \\
& $(100)$ & $(100)$ & $(100)$ & $(100)$ \\
\hline
\end{tabular}

\section{Story formats (editorial content)}

The story formats used by the selected newspapers to report the three candidates also portrayed frames of gender bias. As shown in Table 3, apart from receiving the least coverage across all the story formats, Sonaiya did not get any coverage in terms of hard news. Conversely, Jonathan (54.0\%) and Buhari (46.0\%) received substantial amount of hard news coverage by the newspapers. Curiously, Sonaiya got her scanty media coverage only through features $(n=4 ; 2.6 \%)$. Perhaps because of his incumbency status, Jonathan received the highest amount $(\mathrm{n}=154 ; 53.5 \%)$ of media 
Ojebuyi, B. R. \& Chukwunwike, A. C./ Legon Journal of the Humanities 29.1 (2018)

attention across all story formats.

Table 3: Percentage coverage given to the presidential candidates based on story formats (editorial content)

\begin{tabular}{|l|c|c|c|c|}
\hline Candidates & Hard News & Features & Editorial & Total \\
\cline { 2 - 5 } & $\mathrm{F}(\%)$ & $\mathrm{F}(\%)$ & $\mathrm{F}(\%)$ & $\mathrm{F}(\%)$ \\
\hline Buhari & $58(46.0)$ & $72(46.2)$ & 0 & 130 \\
& & & $(0.00)$ & $(45.1)$ \\
\hline Jonathan & $68(54.0)$ & $80(51.3)$ & 6 & 154 \\
Sonaiya & $0(0.00)$ & 4 & $(100)$ & $(53.5)$ \\
\hline Total & $126(100)$ & $156(100)$ & $(0.00)$ & $(1.4)$ \\
\hline & & $(2.6)$ & $(100)$ & $(100)$ \\
\hline
\end{tabular}

\section{Formats (extra-editorial contents)}

In order to provide the probable link between commercial interest and editorial decision in the context of media framing and gatekeeping, we also accounted for frames of media coverage based on the extra-editorial contents (advertisement, profile pictures, and personality profiles of the candidates). As presented in Table 4, a similar pattern of coverage for the editorial contents also manifests here with Sonaiya receiving only $1.4 \%$ of the total coverage compared to the amounts of coverage given to Jonathan $(52.3 \%)$ and Buhari (46.2\%). Specifically, Jonathan had a total of 95 (53.1\%) advertisements; Buhari had 84 (46.9\%), while Sonaiya had none. 
Ojebuyi, B. R. \& Chukwunwike, A. C./ Gender bais in media representation of political actors

Table 4: Percentage coverage given to the presidential candidates based on extra-editorial contents

\begin{tabular}{|l|c|c|c|c|}
\hline Candidates & Adverts & $\begin{array}{c}\text { Personality } \\
\text { Profile }\end{array}$ & $\begin{array}{c}\text { Profile } \\
\text { Picture }\end{array}$ & Total \\
\cline { 2 - 5 } & $\mathrm{F}(\%)$ & $\mathrm{F}(\%)$ & $\mathrm{F}(\%)$ & $\mathrm{F}(\%)$ \\
\hline Buhari & 84 & 22 & 22 & 128 \\
& $(46.9)$ & $(41.5)$ & $(48.9)$ & $(46.2)$ \\
\hline Jonathan & 95 & 29 & 21 & 145 \\
\hline Sonaiya & $(53.1)$ & $(54.7)$ & $(46.7)$ & $(52.3)$ \\
\hline Total & 0 & 2 & 2 & 4 \\
& $(0.00)$ & $(3.8)$ & $(4.4)$ & $(1.4)$ \\
\hline
\end{tabular}

We further tested the null hypothesis (Ho): There will be no statistically significant difference in the scores for the male aspirants and the female aspirant in terms of media coverage they received during Nigeria's 2015 presidential election. In order to do this, we conducted an independent-samples t-test at 0.005 level of significance. As reported in Tables 5, 6 and 7, we compared the extent of disparity in the amount of media attention given to Sonaiya and her male counterparts-Buhari and Jonathan.

Table 5: Results of t-test on the media coverage and prominence of Buhari and Sonaiya

\begin{tabular}{|l|l|l|l|l|l|l|}
\hline Variable & Sample & Mean & Std. Dev. & T & P-Value & Remark \\
\hline Buhari & 12 & 64.42 & 66.3 & & & \\
\hline & & & & .834 & .001 & Sig \\
\hline Sonaiya & 12 & 2.0 & 2.412 & & & \\
\hline
\end{tabular}

First, in Table 5, we present the t-test results indicating 
disparity of media coverage between Buhari and Sonaiya. The t-test results show that there was a significant difference in the scores for Buhari $(\mathrm{M}=64.4, \mathrm{SD}=66.3)$ and Sonaiya $(\mathrm{M}=2.0, \mathrm{SD}=2.4)$; $\mathrm{t}=0.834, \mathrm{p}=0.001$. The $\mathrm{P}$-value as presented in Table 5 shows that the result is not greater than 0.005 . The results suggest that Buhari received more media attention than did Sonaiya.

Table 6: Results of t-test on the media coverage and prominence of Goodluck Jonathan and Sonaiya

\begin{tabular}{|l|l|l|l|l|l|l|}
\hline Variable & Sample & Mean & Std. Dev. & T & P-Value & Remark \\
\hline Jonathan & 12 & 74.5 & 66.3 & & & \\
& & & & .823 & .001 & Sig \\
\hline Sonaiya & 12 & 2.00 & 2.412 & & & \\
\hline
\end{tabular}

The t-test results on Table 6 show that there was a significant difference in the scores for Jonathan $(\mathrm{M}=74.5, \mathrm{SD}=66.3)$ and Sonaiya $(\mathrm{M}=2.0, \mathrm{SD}=2.4) ; \mathrm{t}=0.823, \mathrm{p}=0.001$. The results statistically means that Jonathan and Sonaiya significantly differ again on the coverage and prominence level they got from the media. In other words, the newspapers reported Jonathan far more than they reported Sonaiya.

Table 7: Results of t-test on the media coverage and prominence presidential candidates

\begin{tabular}{|l|l|l|l|l|l|l|}
\hline Variable & Sample & Mean & Std. Dev. & T & P-Value & Remark \\
\hline Male & 12 & 139.1667 & 126.37666 & & & \\
\hline & & & & .830 & .001 & Sig \\
\hline Female & 12 & 2.00 & 2.412 & & & \\
\hline
\end{tabular}

Table 7 compares the coverage and prominence given to Sonaiya and the two male presidential candidates-Buhari and Jonathan. The t-test results on Table 7 indicate that there was a statistically significant difference in the scores for the male aspirants $(M=139.16, S D=126.37)$ and the female aspirant $(M=2.0$, $\mathrm{SD}=2.41) ; \mathrm{t}=0.830, \mathrm{p}=0.001$. Therefore, our hypothesis is rejected. 
Ojebuyi, B. R. \& Chukwunwike, A. C./ Gender bais in media representation of political actors

Male and female presidential candidates significantly differed on the coverage and prominence of media coverage they received: the male candidates received more media coverage and prominence than the female candidate did.

\section{Discussion}

As established in this study, the selected Nigerian newspapers (i.e. The Punch, The Guardian, and the Daily Sun) skewed their attention in favor of the male presidential aspirants giving comparatively insignificant attention to the only female candidate during the 2015 presidential election in Nigeria. As expected, while the two male presidential aspirants (Jonathan and Buhari), were reported frequently on the front and back pages of the newspapers, the female aspirant (Sonaiya) did not feature at all on the front and back pages of the newspapers. It is also curious to note that Sonaiya was reported only eight times on the inside pages representing just $1.7 \%$ of the total of 464 of reports found on the inside pages whereas Jonathan $(\mathrm{n}=239,51.1 \%)$ and Buhari $(\mathrm{n}=$ $218 ; 46.8 \%$ ) still got more reports on the inside pages. A similar trend is recorded for the length of the stories where Sonaiya got the least attention out of the three presidential aspirants: The two male candidates_-Jonathan $(\mathrm{n}=299 ; 52.9 \%)$ and Buhari $(\mathrm{n}=258$; $45.6 \%$ - got more space than did Sonaiya with only $1.4 \%$ of the total space.

Overall, the t-test results suggest that the media coverage of the presidential candidates in Nigeria's 2015 presidential election on the basis of gender was significantly slanted and as such there is disparity in the coverage of the male and female presidential candidates. Specifically, our results suggest that the Nigerian newspapers have the tendency to report and foreground malepoliticians more than female-politicians during election campaigns.

In terms of the formats of news stories reported about the three presidential candidates, the same trend of skewed attention by media is established. From all the 288 editorial contents analyzed, Mrs. Oluremi Sonaiya of the KOWA Party got negligible four reports representing just $1.4 \%$ of all formats of reports by the newspapers. 
This is a sharp contrast to the amount of media attention given to the other two male presidential candidates - Goodluck Jonathan of the People's Democratic Party (PDP) and Muhammadu Buhari of the All Progressives Congress (APC) who got 154 (53.5\%) and 130 $(45.1 \%)$ respectively of the editorial contents. Apart from being under-reported generally, Sonaiya did not get any newspaper report in the form of hard news, whereas Jonathan (54.0\%) and Buhari $(46.0 \%)$ were reported in the hard news formats. The few reports in editorial content Sonaiya got came only through features $(\mathrm{n}=$ $4 ; 2.6 \%$ ). This is also extremely marginal compared to the amount of feature stories coverage given to Buhari (46.2\%) and Jonathan $(51.3 \%)$.

In addition, the extra-editorial contents (adverts, personality profiles and profile pictures) that were analyzed reflected gender bias and provided the basis for explaining the link between commercial interest and editorial decision as complex constructs in the overall media framing and gatekeeping process (Reese \& Ballinger, 2001; Shoemaker, Eichholz, Kim \& Wrigley, 2001; McManus, 2005; Shoemaker \& Vos 2009). The finding shows that more shares of the extra-editorial content were given to both Jonathan $(\mathrm{n}=145 ; 52.3 \%)$ and Buhari $(\mathrm{n}=128 ; 46.2 \%)$ compared to less than $2 \%$ coverage given to Sonaiya. Although, extra-editorial media contents are not expected to be influenced by pure journalistic values but by the advertisers, who must have paid for the contents to be published (Beam, 2001), the low coverage given to Sonaiya in both editorial and extra-editorial formats suggests that there is a link between the commercial capacity of a news subject and the amount of favorable media attention such a news subject receives (Ferrucci, 2015). News format is part of the macroconstruct journalists employ to frame social reality (Scheufele \& Tewksbury, 2007). Each news format has its editorial relevance and functions. Naturally, for instance, hard news is a news genre that is believed to be factual, unbiased, and not to be sponsored. It is a news format that usually occupies the front pages of newspapers, and is expected to fulfil the social responsibility function of the news media. On the other hand, 
newspaper contents such as adverts, profile interviews, and profile pictures are usually sponsored by the individuals being reported (Deahl, 2017). Paying more attention to hard news, which tends to serve the democratic political system, provides support for public order and enhances security of the state, suggests that the media is socially responsible (McQuail, 2007).

The slightly higher amount of reports recorded by Goodluck Jonathan ahead of Muhammadu Buhari could be attributed to the influence of incumbency. During the election campaigns that this study covered, Goodluck Jonathan was the sitting President of Nigeria and fielded as the presidential flag bearer of the ruling PDP. While Buhari enjoyed the widespread goodwill and strong support of his party (APC), a mega-coalition of different opposition parties that emerged from the terrible disintegration of the PDP, resulting in its (APC's) victory during the election (West Africa Network for Peace-building [WANEP], 2014), Jonathan enjoyed the benefits of incumbency for being the flag bearer of the ruling party. The combined political and financial strengths of the two parties (APC and PDP) could define the media coverage received by their respective presidential candidates and their performances at the presidential polls.

The trend of coverage established in this current study where the female presidential aspirant was neither reported on both the front and back pages of the newspapers nor given coverage in hard news format has some implications. One, the newspapers have tactically used some forms of frames (placement, space, and format) that marginalized the female candidate while male candidates were given prominence. This is because news stories on the front and back pages of newspapers attract more readerships and give more prominence to the news subjects and actors compared to insidepage stories. Two, the fact that Sonaiya was not reported in the hard news format might suggest that the monetary factor had exerted some influence on the media coverage of presidential candidates. Perhaps, the frequency of times Sonaiya could sponsor some adverts had influenced the number of stories done on her campaign, her visibility being limited only to profile interviews and profile 
pictures.

These two phenomena have implications for both Media Framing Theory (McCombs, 2004; Druuckman, 2007; Entman (2007) and the Market-Oriented Journalism Theory (McManus, 2005; Ojebode and Owacgiu, 2013). For instance, as Entman (2007) explains, media framing comes to effect when news editors select some fragments of issues of public interest or report some individuals and make them more significant and salient than others in a communicating context. Also, Chong and Druckman (2007) believe that frame in news reporting is not only about the words and phrases the journalist uses to construct certain social reality, but it is also about use of visual elements and the presentation styles that the news reporters or their editors employ to present an issue or a news actor. In reference to the findings in our current study, the nature of the frames used by the selected newspapers to report the presidential aspirants, where the male candidates enjoyed greater prominence in terms of placement and frequency of coverage, could have some effect on the decisions of the electorate at the point of casting their votes for the respective candidates. In other words, the male candidates (Jonathan and Buhari) that got more attention from the news media, compared to the female aspirant (Sonaiya) that received insignificant media attention, won more votes from the electorate-APC's Buhari: 15,424,921; PDP's Jonathan: 12,853,162; KOWA's Sonaiya: 13,076 (Independent National Electoral Commission [INEC], 2015).

Further, the Market-Oriented Journalism Theory posits that modern journalism is not just about reporting news; but it is also about giving prominence to events or personalities that will bring economic benefit to the news agency. Of course, it has been empirically established that variables such as market orientation affect the final contents that the news media gives to the mass audience (Ferrucci, 2015). Therefore, for electoral activities of the presidential aspirants to be reported by the news media, the political candidates must have sponsored their campaigns, political rallies, profiles interviews, and pictures the media reported. As Aluaigba 
(2015) and IPC (2015) have unanimously stated, in order to have intense media coverage of electioneering, which could mean a stiff electoral competition, the political candidates would need to have some financial backing. . The foregoing position reaffirms the findings by Agbalajobi (2010), who traced the unequal media coverage of gender in political race to the lack of financial strength among other factors. Our current findings also corroborate this view. Given their political affiliations, the flag bearers of the ruling PDP and the mega-opposition party APC respectively-Buhari and Jonathan-were expected to be in stronger financial positions to influence the media compared to Sonaiya, who was sponsored by a relatively weaker and smaller political party_KOWA.

Our current study has further reinforced the arguments put forward by Oyesomi and Oyero (2012) and Ette (2017) that the media's projection of female aspirants in politics is low as opposed to that of the male politicians. The implication is that this biased media coverage naturally puts the female aspirants at the disadvantaged position during electoral contests. It should be noted, however, that the findings in our current study present a scenario contrary to what Hayes and Lawless (2015) found from their a study of newspaper coverage of the 2010 US House of Representative mid-term election. Their study established that male and female candidates received almost equal mention in the newspapers. This difference could be attributed to the contextual peculiarity of most of African countries including Nigeria, where women are culturally regarded as being inferior (Mudhai, Wright and Musa, 2016). Hence, they are not expected to take dominant roles in politics and public administration of the patriarchal setting (Ette, 2017).

\section{Conclusion}

In this study, we have examined, from the media lens, the construct of gender which has been debated by scholars to be a disadvantage to the females, especially in the political terrain. Our findings show a wide disparity between male and female politicians in terms of the amount of attention they receive from the news media 
during electioneering. Nigerian newspapers gave prominence and intense coverage to male presidential candidates while they underreported the female presidential candidate. We infer that apart from the hackneyed stereotype that women are always marginalized in politics, the disparities in the media coverage of male and female candidates during political contests could be a reflection of the financial strength of the two genders to dominate the media space, which could eventually determine their level of success during elections. It is, therefore, recommended that the institutions responsible for the regulation of the electoral process in Nigeria, and in other African countries with similar trends, to provide a mechanism that empowers both male and female politicians in such a way that they both have equal advantages during electioneering. 


\section{References}

Ace Project (2012). Media and elections. Retrieved from https://aceproject.org/ ace-en/topics/me

Agbalajobi, D.T. (2010). Women's participation and the political process in Nigeria: problems prospects. African Journal of Political Science and International Relations, 4 (2), 75-82.

Akinfeleye, R. A. (2008). Broadcast pluralism: The monopoly of the airwaves by the government-owned stations. In Akingbulu, A. (Ed.), Rooting for community radio in Nigeria (pp. 14-16). Ikeja: Institute for Media and Society.

Aluaigba, A. (2015). Taming a lion: Monitoring campaign finances of political parties prior to the 2015 elections in Nigeria. Paper presented at the twoday national conference on the 2015 general elections in Nigeria: The real issues, organized by the Electoral Institute, Abuja, July 27 to 28, 2015.

Amusan, L. (2014). Evaluating the gender content of the Amnesty programme in the Niger Delta of Nigeria: Any concern for the socio-economic development of women? Gender \& Behaviour, 12 (3), 5924-5935.

Anorue, L.I., Obayi, O.M., \& Onyebuchi, C.A. (2012).The mass media gender balance and politics in Nigeria: An assessment. AFRREN LALIGENS: International Journal of Language, Literature and Gender Studies, 1(3), 14-35

Atkinson, L.R., \& Krebs, T. B. (2008). Press coverage of mayoral candidates: The role of gender in news reporting and campaign issue speech. Journal of Political Research, 61(2), 239-252.

Ayodele, O. (1988). Objectivity, sycophancy and the media reality in Nigeria. Africa Media Review, 3(1), 106-120.

Barzinlai-Nahon, K. (2008). Towards a theory of network gatekeeping: A framework for exploring information control. Journal of the American Society for Information Science and Technology, 59(9),1493-1512. DOI: 10.1002/asi.20857.

BBC News (2015). How Nigeria's presidential election works. Retrieved from www.bbc.com/news/worldafrica-31111572 [

Beam, R.A. (1998). What it means to be a market-oriented newspaper. Newspaper Research Journal,19 (3), 2-20.

Beam, R. A. (2001). Does it pay to be a market-oriented daily newspaper? Journalism \& Mass Communication Quarterly, 78 (3), 466-483.

Bucy, E. K., D’Angelo, P., \& Bauer, N. M. (2014). Crisis, credibility, and the press: A priming model of news evaluation. The International Journal of Press/Politics, 19(4), 453-475. DOI: 10.1177/1940161214541682

Carkoglu, A., Baruh, L., \& Yıldırım, K. (2014). Press-party parallelism and polarization of news media during an election campaign: The case of the 2011 Turkish elections. The International Journal of Press/Politics, 19(3), 295-317.

Chong, D., \& Druckman, N. J. (2007). A theory of framing and opinion formation in competitive elite environment. Journal of Communication, 57, 99-118. 
Ojebuyi, B. R. \& Chukwunwike, A. C./ Legon Journal of the Humanities 29.1 (2018)

Deahl, R. (2017). Hard news: How does it differ from other types? The balance. [Blog post] Retrieved from https:/www.thebalance.com/hard-news-how-does-it-differfrom-other-types-2316022

Dimitrova, D.V., Shehata, A., Strömbäck, J., \& Nord, L. W. (2014). The effects of digital media on political knowledge and participation in election campaigns: Evidence from panel data. Communication Research, 41(1), 95-118. DOI: $10.1177 / 0093650211426004$

Druckman, J. N. (2001). The implications of framing effects on citizen competence. Political Behaviour, 23(3), 225-256.

Entman, R. M. (2007). Framing bias: Media in the distribution of power. Journal of Communication, 57, 163-173.

Entman, R.M. (1993). Framing: Toward clarification of a fractured paradigm. Journal of Communication, 43(4), 51-58.

Ette, M. (2017). Where are the women? Evaluating visibility of Nigerian female politicians in news media space, Gender, Place \& Culture, 24(10), 14801497, DOI: 10.1080/0966369X.2017.1387104

Ferrucci, P. (2015).Primary differences: how market orientation can influence content. Journal of Media Practice, 16(3), 195-210, http://dx.doi.org/10.1080/14682753 .2015 .1116754

Hayes, D., \& Lawless, J.L. (2015). A non-gendered lens? Media, voters and female candidates in contemporary congressional elections. American Political Science Association, 13(1), 95-118

Hayes, D., Lawless, J. \& Baitinger, G. (2014). Who cares what they wear? Media, gender and the influence of candidates' appearance. Social Science Quarterly, 95 (5), 1195-1212

Hernes, H.M. (1987). Welfare state and women power: Essays in state feminism. Oslo: Norwegian University Press

Ibraheem, I.A., Ogwezzy-Ndesikka, O. A. \& Tejumaiye, A. (2015). Beyond influence: Media and the 2015 presidential election. Retrieved from www.inecnigeria. org/.../2015/

Independent National Electoral Commission(2015). Summary of result: 2015 presidential election. Abuja, Nigeria: INEC. Retrieved from http://www.inecnigeria.org/wpcontent/uploads/2015/04/summary-of-results.pdf

Inter-Parliamentary Report (2007). Women in parliament in 2007: The year in perspective. Retrieved from www.ipu.org

Isika, G. U. (2016). The 2015 presidential election campaign: Issues and concerns of multi-party democracy in Nigeria. In D. Wilson (Ed.), Mass media and the electoral process in Nigeria (pp. 47-58). Uyo: ACCE

McCombs, M. E. (2004). Setting the agenda: The mass media and public opinion. Malden, MA: Polity Press

McGregor, J. (2010). Restating news values: Contemporary criteria for selecting the news. Massey University. Retrieved from http://praxis.massey.ac.nz/fileadmin/ praxis/papers/JMcGregorpaper

McKain, A. (2005). Not necessarily not the news: Gatekeeping, remediation, and the Daily Show. The Journal of American Culture, 28 (4), 415-430 
Ojebuyi, B. R. \& Chukwunwike, A. C./ Gender bais in media representation of political actors

McManus, J. (2005). Market-based model of news production. Communication Theory, 5 (4), 301-338

McQuail, D. (2007). McQuail's mass communication theory. London: Sage.

Mudhai, O. F., Wright, B., \& Musa, A. (2016). Gender and critical media-information literacy in the digital age: Kenya, South Africa and Nigeria. Journal of African Media Studies, 8 (3), 267-280, doi: 10.1386/jams.8.3.267_1

Nassanga, L. G. (2008). Journalism ethics and the emerging new media culture of radio talk shows and public debates (Ekimeeza) in Uganda. Journalism, 9(5), 646-663 DOI: $10.1177 / 1464884908094163$

Ngwu, O. L. (2015). Influence of ownership on professional journalism practice in Nigeria: A study of Ebbc, Ebonyi and Dream FM, Enugu. (M.A. Dissertation). University of Nigeria, Nsukka. Retrieved from http://repository.unn.edu.ng:8080/ xmlui/bitstream/handle/123456789/4540/NGWU\%2C\%20OGONNAYA\%20 LYNDA.pdf?sequence $=1$ \&isAllowed $=\mathrm{y}$

Ojebode, A., \& Owacgiu, J. A. (2013). Never again say 'land': Understanding media silence on post-war conflicts in Northern Uganda, Journal of Communication and Language Arts, 4 (1), 37-61.

Ojebode, A. (2009). Public service versus profit-making: The Nigerian broadcast sector in a neoliberal economy In A. A. Olorunnisola (Ed.), Media and communications industries in Nigeria: Impacts of neoliberal reforms between 1999 and 2007 (pp. 59-78). New York: Edwin Mellen Press.

Ojebuyi B. R. (2012). Secondary gatekeeping in radio stations in Oyo State, Nigeria. (Doctoral thesis). University of Ibadan, Nigeria

Olorunnisola, A. A. (Ed.). (2009). Media and communications industries in Nigeria: Impacts of neoliberal reforms between 1999 and 2007. New York: Edwin Mellen.

Onyenwere, J. C. (2017). Women and governance: A case study of Nigerian women. (B. A. Dissertation). School of Business and Governance, Tallinn University of Technology, Estonia. Retrieved from https://digi.lib.ttu.ee/i/file. php?DLID $=9501 \& \mathrm{t}=1$

Oso, L. (2012). Press and politics in Nigeria: On whose side? LASU Inaugural Lecture Series, 47th Edition. Lagos: Lagos State University.

Oyesomi, K., \& Oyero, O. (2012). Media coverage of women's participation in the 2011 general elections in Nigeria. The Nigerian Journal of Communication, 10 (1), 136- 156

Quadri, M. O. (2015). Women and political participation in the 2015 general elections: Fault lines and mainstreaming exclusion. A paper presented at a two-day national conference on "2015 General Elections: The real issues", organized by the Electoral Institute, INEC Abuja on 27th-28th July. Retrieved from http:// inecnigeria.org/wp-content/uploads/2015/07/Conference-Paper-by-MaryamOmolara-Quadri.pdf

Reese, S. D., \& Ballinger, J. (2001). The roots of a sociology of news: Remembering Mr. Gates and social control in the newsroom. Journalism \& Mass Communication Quarterly,78 (4), 641-658 
Ojebuyi, B. R. \& Chukwunwike, A. C./ Legon Journal of the Humanities 29.1 (2018)

Salawu, A. (2006). Rich history, uncertain future, Rhodes Journalism Review, 26, 55-56. Retrieved fromhttp:/journals.co.za/docserver/fulltext/rujr/2006/26/rujr_n26_a27. id\&accname= guest\&checksum=4C017FDC222D6EAE004547A7F5A3BAE9

Sankore, R. (2017). View from the ground (Nigeria): The Poor state of gender balance. New African, 576, 56. Retrieved from http://eds.b.ebscohost.com.nwulib. nwu.ac.za/eds/pdfviewer/pdfviewer?vid $=9 \&$ sid $=67 \mathrm{a} 2 \mathrm{~b} 36 \mathrm{~b}-\mathrm{fb} 0 \mathrm{~b}-4031-\mathrm{b} 3 \mathrm{ed}-$ 947e6cfdb343\%40sessionmgr 120

Scheufele, D. A., \& Tewksbury, D. (2007). Framing, agenda setting and priming: The evolution of three media effects models. Journal of Communication, 57, 9-20.

Severin, W. J., \& Tankard, J. W. (Jr.) (2001). Communication theories: Origins, methods, and uses in the mass media. New York: Addison Wesley Longman.

Shepard, A. C. (1999). Gatekeepers without gates. American Journalism Review, 21 (2), 22-29

Shoemaker, P. J. (2006). News and newsworthiness: A commentary, Communications, 3 (1), 105-111.

Shoemaker, P. J., \& Vos, T. P. (2009). Gatekeeping theory. New York: Routledge

Shoemaker, P. J., Eichholz, M., Kim, E., \& Wrigley, B. (2001). Individual and routine forces in gatekeeping. Journalism and Mass Communication Quarterly, 78 (2), 233-246

The Vanguard [online] (2015). Nigeria's first female presidential candidate done with 'cheerleading', 18 March, 2015. Retrieved from http://www.vanguardngr. com/2015/03/nigerias-first-female-presidential-candidate-done-withcheerleading/

The Vanguard [online] (2015). Parties spend N4.9bn on political adverts. Retrieved from http://www.vanguardngr.com/2015/03/parties-spend-n4-9bn-on-politicaladverts/

Thorsten, N. (2005). Gender inequality in politics". Retrieved from http://www.koed.hu/ mozaik15/thorsten.pdf-

West Africa Network for Peace-Building [WANEP] (2014). Nigeria's 2015 general elections: Crumbling or consolidating democracy? Retrieved from https://www. files.ethz.ch/isn/182913/pb_nigeria_april_2014.pdf- 